\title{
管水路流れにおける3方向接合円形マンホール のエネルギ一損失特性 \\ ENERGY LOSS AT THREE-WAY CIRCULAR MANHOLE UNDER SURCHARGE FLOW
}

\author{
荒尾慎司 ${ }^{1}$ ・森山克美 ${ }^{2} \cdot$ 淺田純作 $^{1} \cdot$ 広瀬 $^{\text {望 }^{3} \cdot \text { 楠田哲也 }}{ }^{4}$ \\ Shinji ARAO, Katsumi MORIYAMA, Jyunsaku ASADA, Nozomu HIROSE, Tetsuya KUSUDA \\ 1 正会員 工博 松江工業高等専門学校教授 環境・建設工学科 ( \\ 2 正会員 工博 九州共立大学教授 工学部環境土木科（干807-8585 北九州市八幡西区自由ケ丘 1-8) \\ 3 正会員 工博 松江工業高等専門学校准教授 環境・建設工学科 ( \\ 4 フェロー会員 工博 北九州市立大学教授 国際環境工学部（†808-0135 北九州市若松区ひびきの 1-1）
}

The energy loss at manholes in a storm sewer network is often compared with the friction loss in pipes under a surcharge flow. It is important to estimate the energy loss at manholes exactly in the design of a storm sewer network and in a flood-analysis. Some researchers have already investigated the energy loss at three-way manholes. However, the relationship between the energy loss and the water depth in manholes has not been enough studied yet.

In this study, the effect of the water depth and the ratio of the flow rates in the lateral and in the downstream pipes on the energy loss at a three-way circular manhole was investigated. This study also proposed a modified formula for energy loss coefficients described in Urban Drainage Design Manual, USA (2001) for the three-way manhole.

Key Words : Urban storm drainage, energy loss, three-way manhole, model test

\section{1. はじめに}

近年，全国各地の市町村で洪水ハザードマップが公表 され，住民が避難行動をとる上で有用な資料となってい る.しかし，公表されている洪水ハザードマップにおい て, 内水氾濫が考慮されていない場合, 実際に浸水して いる区域を計算では予測できていないケースも生じてお り問題となっている.

内水汇濫計算において, 降雨強度, 降雨の空間分布, 地表面の平面二次元氾濫解析モデルのメッシュサイズ, 地表面の道路, 宅地や粗度係数の設定, 雨水管をどこま でモデル化するかなどにより, 浸水面積, 浸水深や氾濫 流の流速が異なってくる. 道路や宅地に降った雨は雨水 マスを通して雨水管に流入するため, 雨水の流れをより 正確に計算するには, 雨水管をモデル化する必要がある. 雨水管をモデル化する上で, 無視できないのが雨水管を 接続するマンホールでの損失である. 従来の研究より, マンホールでの損失が管きょの摩擦損失に匹敵するほど
大きくなることもあり，決して無視しえないことが明ら かにされている ${ }^{1-6)}$. マンホールでの損失を全く無視する か，考慮したとしても過小に見積もつた損失係数を与え て計算を行うと，実際には浸水している区域が，計算で は浸水しないということも起こりうる. このような計算 結果を基に，住民の避難行動計画を策定するのは極めて 危険であり，より正確な洪水ハザードマップを住民に周 知させることが，減災上，非常に重要である.

マンホールでの損失に関しては，流入管 1 本と流出管 1 本が接続する 2 方向接合マンホールにおいて，著者ら が既に定式化している ${ }^{7)}$. しかし，T字路や十字路の交差 点下に設置されているマンホールに関しては，流入管の 本数が増加し, 流入・流出管の間には段差を有すること もあることから, 考慮しなければならない構造上の変数 はより多くなる. このようなことから, 現在でも, 全て の変数を組み込んだ定式化が図られておらず，これまで に開発されたマンホール損失の算定式では適用範囲が限 られている ${ }^{6}$. 
そこで本論文では, T 字路下の 3 方向接合円形マンホー ルを対象として，管内径，管内流量，マンホール内の水 深を種々変化させた実験を行い，マンホールのエネルギ 一損失特性を明らかにする. さらに，これまでに考案さ れている算定式の中でも適用範囲が広く有用と考えられ る Urban Drainage Design Manual (2001) ${ }^{8}$ (以下ではUDDM と表記)を取り上げ，本式の問題点を実験データにより明 らかにするとともに，実測值をより正確に算定できる修 正式を提示する.

\section{2. 従来の研究及び課題}

管水路流れにおける 3 方向接合マンホールでの損失に 関する従来の主な研究は, Sangster ら (1961) ${ }^{9)}$, Marsalek (1985) ${ }^{10)}$, Lindvall (1984) ${ }^{11)}, \operatorname{UDDM}(2001)^{8)}$, 著 者ら (2003) ${ }^{12), 13)}$ などによって行われている．著者らを除 く研究では，3方向接合マンホールにおけるエネルギー 損失係数や圧力損失係数の算定式が種々考案されている ものの, マンホールや接続管路に関わる構造上の変数が 全て考慮されているわけではなく, 算定式の適用範囲に 制限がある，一般的に，道路勾配が急なところでは，設 計流速が上限值 ${ }^{14)}$ を超えないように流入・流出管との間 に段差を設けるが，平坦なところでも，地中の他の埋設 物との位置関係によりやむを得ず段差を設けることがあ る. しかし, 従来の研究で段差を考慮して検討を行って いるものは少ない 6$), 8), 13)$.

3 方向接合マンホールのエネルギー損失係数を算定す る上で, 最も適用範囲が広いのが UDDM に掲載されてい る式である．本式は，管路勾配が緩勾配である場合に利 用される. その式形を以下に示す.

$$
\begin{gathered}
K_{E}=K_{o} C_{D} C_{d} C_{Q} C_{P} C_{B} \\
K_{o}=0.1\left(\frac{b}{D_{d}}\right)(1-\sin \theta)+1.4\left(\frac{b}{D_{d}}\right)^{0.15} \sin \theta \\
C_{D}=\left(\frac{D_{d}}{D_{i}}\right)^{3} \\
C_{d}=0.5\left(\frac{y}{D_{d}}\right)^{0.6} \\
{\left[0 \leq \frac{\mathrm{y}}{D_{d}} \leq 3.2, \frac{\mathrm{y}}{D_{d}}>3.2 \text { then } C_{d}=1\right]} \\
C_{Q}=(1-2 \sin \theta)\left(1-\frac{Q_{i}}{Q_{d}}\right)^{0.75}+1 \\
C_{P}=1+0.2\left(\frac{z}{D_{d}}\right)\left(\frac{z-y}{D_{d}}\right)
\end{gathered}
$$

ここに, $b$ はマンホールの内径, $D_{d}$ は流出管の内径, $D_{i}$ は流入管の内径, $y$ はマンホール底面から水面までの距離 (水深), $K_{o}$ はマンホール径比 $\left(b / D_{d}\right)$ と流入・流出管の 接続角度 $(\theta)$ に関する係数, $C_{D}$ は流入・流出管の管径比
$\left(D_{d} / D_{i}\right)$ に関する係数, $C_{d}$ はマンホール内の水深比 $\left(y / D_{d}\right)$ に関する係数(ただし，この係数には，マンホール内の渦 による損失の増大までは考慮されていない)， $C_{Q}$ は流入・ 流出管の流量比 $\left(Q_{i} / Q_{d}\right)$ に関寸る係数, $C_{P}$ は突入流

(Plunging flow）に関する係数で，いずれの管路からも突 入流がなく，全て管水路流れである場合は， $C_{P}=1$ とし て (6)式を考慮しなくてよい. $z$ は最も高いところにある 流入管の流れと流出管の中心線との鉛直距離である. $C_{B}$ はマンホールの底面形状に関する係数で，マンホール底 面に接続管路の $1 / 2$ のインバートが設置されている場合, $C_{B}=0.95$ とする.

（1）式には，全ての管が管水路流れになったとき，流 入・流出管の段差が考慮されておらず，段差の影響が無 視できない場合に，本式を用いるとマンホールでの損失 を過小に見積もることとなり，実際には溢れているのに， 計算では溢れないという結果になることも起こりうる.

\section{3. 実験装置及び実験方法}

\section{（1）実験装置}

本研究で用いている実験装置(実規模の $1 / 5$ の縮小模 型)の概要を図-1 に示寸. マンホール底面には，日本で一 般的に用いられている管内径の $1 / 2$ に相当するインバー トが設置されている.

\section{（2）実験方法}

(1) 2 ケ所の流量調節バルブにより，流れを surcharge に して上流管流量 $Q_{u}$ と横流入管流量 $Q_{l}$ を所定の流量 に設定する.

(2)下流管内壁頂部から水面までの距離をマンホール水

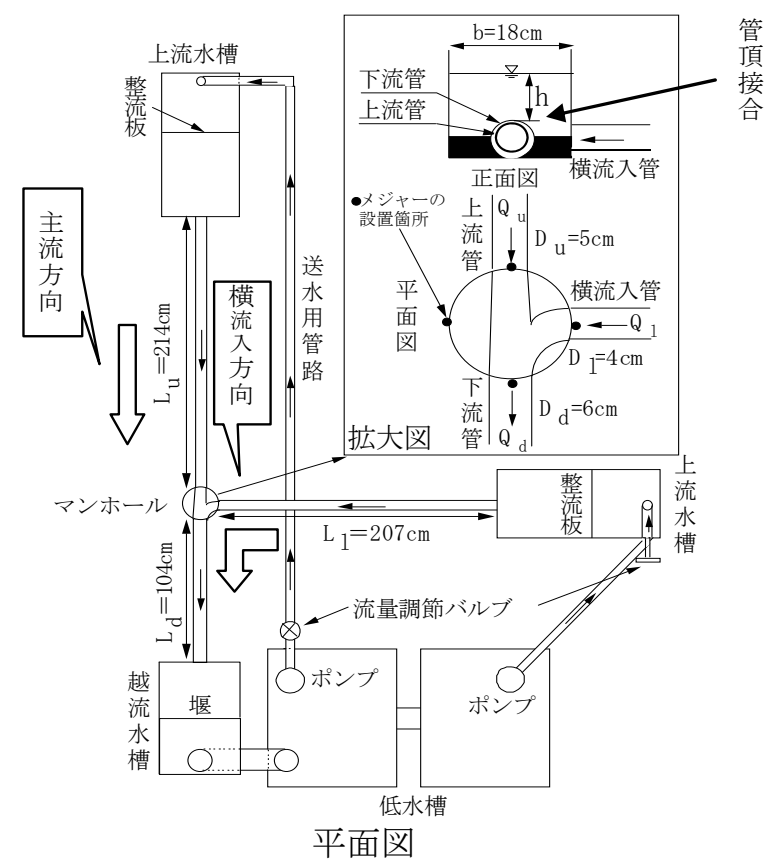

図-1＼cjkstart実験装置の概要（平面図） 
深 $h$ とし，それが所定の值になるように下流管末端 部の越流水槽内の堰高を調節する.

(3)マンホール水深 $h$ は, マンホール外壁に取り付けた 4 ヶ所のメジャーにより測定し，それらの平均值を 測定值とする.

(4)上・下流管及び横流入管にそれぞれ 3 ヶ所ずつ取り 付けたマノメーターによって管内の圧力水頭を測定 し，これに速度水頭 $\left(V^{2} / 2 \mathrm{~g}\right)$ を加えたものからエネ ルギー線を計算することにより，マンホール部のエ ネルギ一損失水頭 $\Delta E$ を求める (図-2 参照).さらに, (7) 式によりエネルギー損失係数 $K_{e *}$ を算定する. ま た，（8)式により圧力損失係数 $K_{p *}$ を算定できる.

$$
\begin{gathered}
K_{e *}=\frac{\Delta E}{V_{d}^{2} / 2 \mathrm{~g}} \\
K_{p *}=K_{e *}+1-\frac{V_{*}^{2}}{V_{d}{ }^{2}}
\end{gathered}
$$

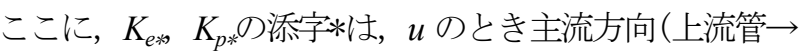
下流管)を，l のとき横流入方向(横流入管一下流管)を表 す. $V_{d}$ は下流管の断面平均流速, $\mathrm{g}$ は重力加速度である.

\section{（3）実験条件}

実験(Type A)の条件は, 既往の研究 (Type B, Type C) 12), 13)も含め, 表-1，表-2 に示す通りである.

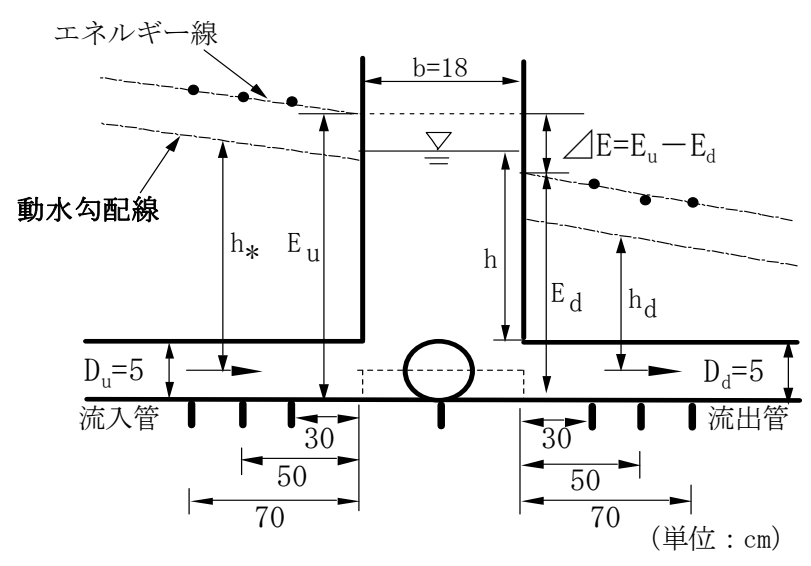

図-2 マンホールのエネルギ一損失水頭 $\Delta E$ の定義

表-1 接続管の管内径

\begin{tabular}{|c|c|c|c|}
\hline 管路の組み合わせ & 横流入管内径 & 上流管内径 (主流方向) & 下流管内径 \\
\hline Type A & $4 \mathrm{~cm}$ & $5 \mathrm{~cm}$ & $6 \mathrm{~cm}$ \\
\hline Type B & $5 \mathrm{~cm}$ & $5 \mathrm{~cm}$ & $6 \mathrm{~cm}$ \\
\hline Type C & $5 \mathrm{~cm}$ & $5 \mathrm{~cm}$ & $5 \mathrm{~cm}$ \\
\hline
\end{tabular}

表-2 流量比の設定

\begin{tabular}{l|l|l|l|l|l|l|l|l|l|} 
実験ケース & No. 1 & No. 2 & No. 3 & No. 4 & No. 5 & No. 6 & No. 7 & No. 8 & No. 9 \\
\hline
\end{tabular}

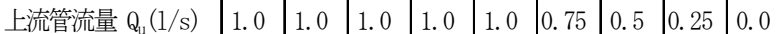

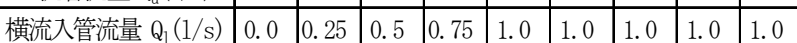

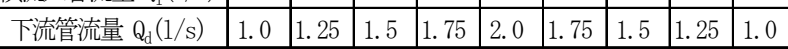
\begin{tabular}{l|l|l|l|l|l|l|l|l|l|} 
流量比 $Q_{1} / Q_{d}$ & 0.0 & 0.2 & 0.33 & 0.43 & 0.5 & 0.57 & 0.67 & 0.8 & 1.0 \\
\hline
\end{tabular}

\section{4. 実験結果及び考察}

（1）マンホール内の水深比、管径比及び流量比の影響 a) 主流方向のエネルギ一損失係数

図-3 から図-5 に流量比 $Q_{l} / Q_{d}=0,0.5$ 及び 1 とした場合 の主流方向のエネルギー損失係数 $K_{e u}$ とマンホール内の 水深比 $h / D_{u}$ との関係を示寸. 流量比 $Q_{l} / Q_{d}$ が 0 の場合, $h / D_{u}$ が 0.5 付近で水面に流下方向に左右に分離する渦や 単一方向回転渦などが発生するため，損失が増大寸る. 横流入管からの流入量の割合が増加すると，損失係数が 極大となるときの $h / D_{u}$ は 1 付近から 2.5 付近の值をとる ことがわかる. $h D_{u}$ が 2 以上のところで損失係数が大き く変化しているケースは，水深が深くなるため鉛直方向 に回転するスケールの大きな渦も影響しているものと推 察される. また，水深比の変化に伴う損失係数の変化状 況は，流量比や管径比によってかなり異なる。これは, マンホール内での渦構造が複雑であるためと考えられる. 渦構造と損失係数との関係に関しては, 別途検討寸る必 要がある. 3本の管内径をいずれも $5 \mathrm{~cm}$ としたもの (Type C）と下流管の管内径のみを $6 \mathrm{~cm}$ と大きくしたもの (Type B）を比較すると，後者の方が損失係数は大きくなってい る.これは，(7）式に示すように，マンホールでの損失 水頭を下流管の速度水頭で除しているからであり，見掛 け上損失係数が大きくなっているだけある. 実際には, 下流管の管内径が大きくなった分だけ，下流管での流れ の急縮後の急拡による損失水頭は小さくなる. 主流方向 の上流管と下流管の内径をそれぞれ $5 \mathrm{~cm} ， 6 \mathrm{~cm}$ とし，横 流入管の内径を $5 \mathrm{~cm}$ から $4 \mathrm{~cm}$ （Type A）にすると，横流 入管からの流入速度が大きく，上流管からの流入水が流 下しにくくなることや，上流管と横流入管からの流入水 の衝突により失うエネルギー損失が横流入管の内径を $5 \mathrm{~cm}$ としたものよりも大きくなることなどから, 流量比 $Q_{l} / Q_{d}$ が 0.5 のとき, Type B よりも損失は大きくなる.

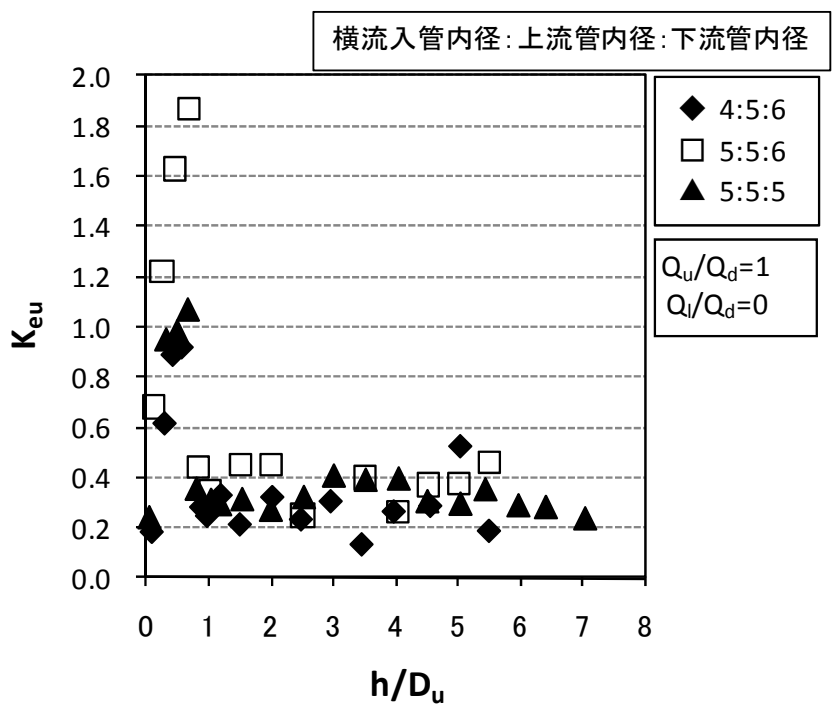

図-3 主流方向の $K_{e u}$ と $h / D_{u}$ の関係 $\left(Q_{l} / Q_{d}=0\right)$ 


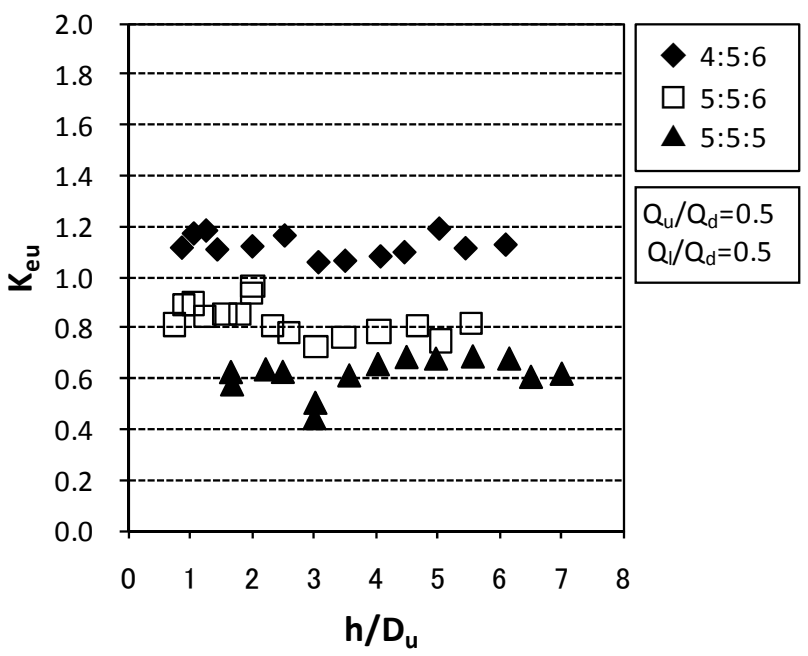

図-4 主流方向の $K_{e u}$ と $h / D_{u}$ の関係 $\left(Q_{l} / Q_{d}=0.5\right)$

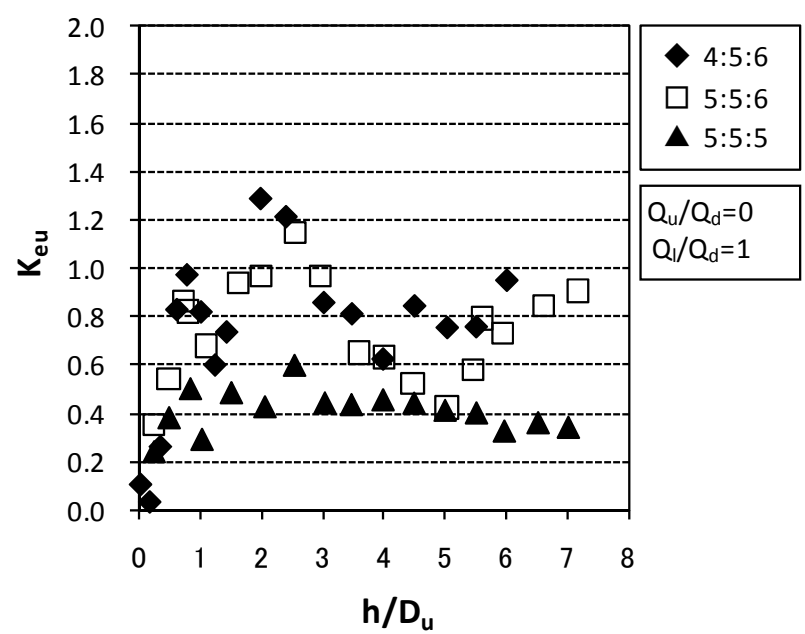

図-5 主流方向の $K_{e u}$ と $h / D_{u}$ の関係 $\left(Q_{l} / Q_{d}=1\right)$

\section{b）横流入方向のエネルギ一損失係数}

図-6から図-8 に流量比 $Q_{l} / Q_{d}=0,0.5$ 及び 1 とした場合 の横流入方向のエネルギー損失係数 $K_{e l}$ とマンホール内の 水深比 $h / D_{u}$ との関係を示寸. 損失係数は流量比 $Q_{l} Q_{d}$ が 1 のときに最大, 0 のときに最小となり，しかも流量比によ って損失係数が大きく異なることがわかる.この理由は, 上流管流量が小さいと，横流入管からの流れがマンホー ル内壁へ衝突し，損失が大きくなり，逆に横流入管流量 が小さくなると, 速度水頭が小さくなり, 横流入管のエ ネルギー水頭が下流管のエネルギー水頭に近づくためで ある. また, 流量比が 0 のとき損失係数が負の值となっ ている. これは, 横流入管の速度水頭 $\left(V^{2} / 2 \mathrm{~g}\right)$ が 0 となる ことから，下流管とマンホールの接合点におけるエネル ギ一水頭よりも横流入管のエネルギー水頭 (=圧力水頭) が小さくなるからである. また，流量比が 1 のとき，い ずれの管径比でも，マンホール内の水深比が 2 付近で損 失係数が極大值をとることがわかる. これは, 水平方向 に回転するスケールの大きな渦の影響によると考えられ る.

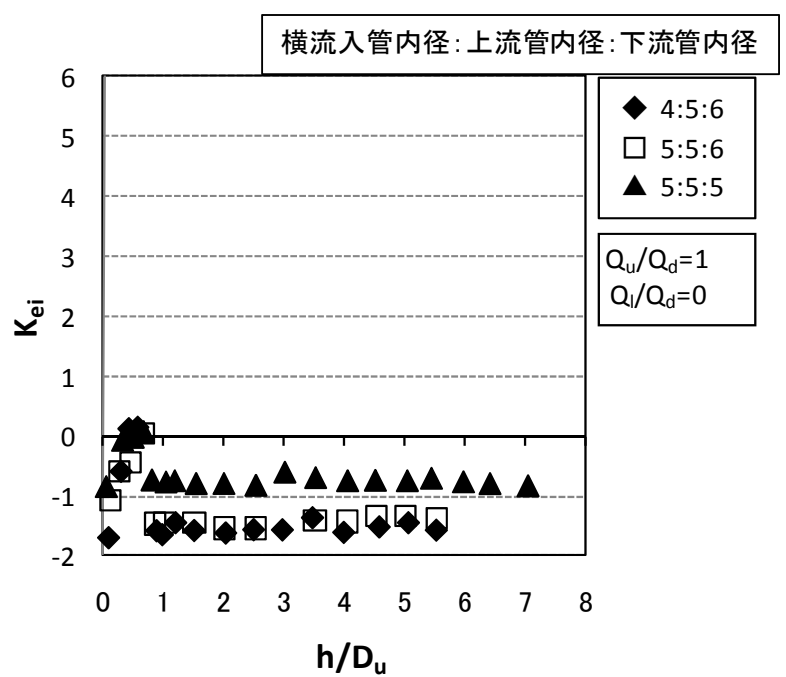

図-6 横流入方向の $K_{e l}$ と $h / D_{u}$ の関係 $\left(Q_{l} / Q_{d}=0\right)$

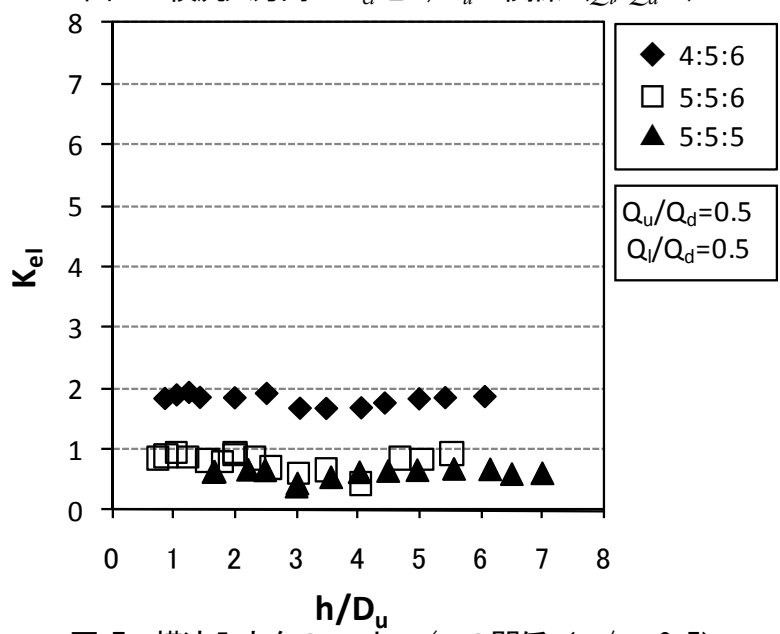

図-7 横流入方向の $K_{e l}$ と $h / D_{u}$ の関係 $\left(Q_{l} / Q_{d}=0.5\right)$

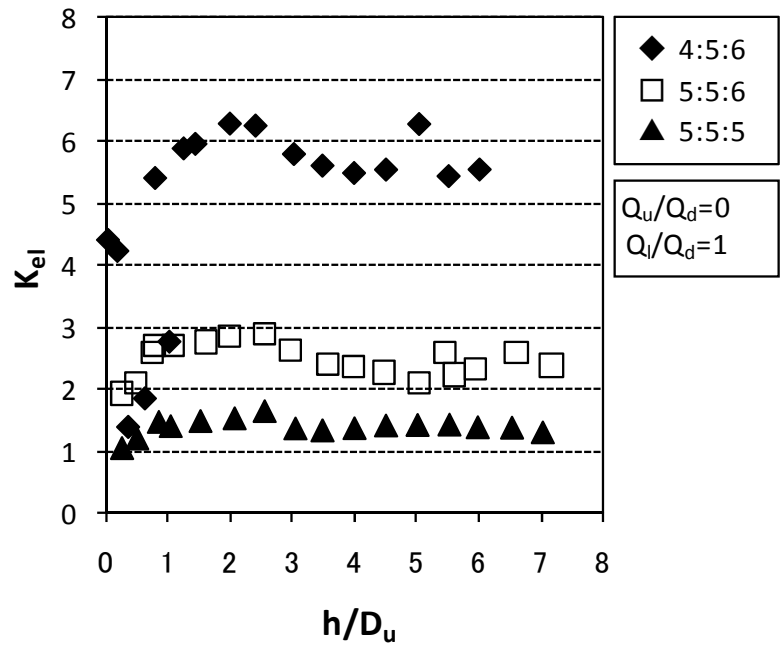

図-8 横流入方向の $K_{e l}$ と $h / D_{u}$ の関係 $\left(Q_{l} / Q_{d}=1\right)$

c) $\left.\operatorname{UDDM}(2001)^{8}\right)$ による計算式の適用と問題点

図-9 と図-10 にそれぞれ主流方向，横流入方向のエネ ルギー損失係数と流量比 $Q_{l} / Q_{d}$ との関係を示寸. 図中に はUDDMに掲載されている式の中で，(1)式から（3)式及 び(5)式を用いたときの損失係数の計算值を示す．なお， 計算值では, 水深の変化までは考慮しておらず，(4)式の $C_{d}$ は 1 としている. 図-9 に示すように, 主流方向の計算 
值では，2本の曲線しか現れない．これは(3)式で，管径 比の影響を主流方向 (上流管一下流管) で表現しており,

Type A と Type B は管径比 $D_{d} / D_{i}=6 / 5=1.2$ となり, 同じ值 になることによる. 主流方向のエネルギー損失係数 $K_{e u}$ は, 流量比 $Q_{l} / Q_{d}$ が 0.5 付近のとき最大となっている.こ れは前述したように，上流管流量と横流入管流量が同程 度のときに，流水間の衝突に伴う損失が大きいことによ ると考えられる. 実測值と計算值を比較すると, Type B やType Cの計算值では流量比が大きくなるにつれて損失 係数は増加しており, 実測值とは合致していないものの, 実測值に近い值となっている. しかし，Type Aに関して は，流量比によっては，実測值よりもかなり小さい值に なっており，計算式では再現できていない.

一方, 図-10 に示すように, 横流入方向のエネルギ一損 失係数 $K_{e l}$ は, 前述したように流量比 $Q_{l} / Q_{d}$ が 1 のとき最 大，0のとき最小となる. UDDM に掲載されている式を 適用すると, 横流入方向の損失係数に関しては, 流量比 が 0.4 付近から 1 の間では実測值をよく再現しているが, 流量比が小さくなるにつれて, 計算値との差が大きくな っている.これは，(5)式において，流入・流出管の接続 角度 $\theta$ を 90 度とした場合, 横流入量を 0 にすると, $C_{Q}$ が常に 0 となるからである.

\section{（2）修正式の提示と今後の検討課題}

前述したように, UDDMに掲載されている式によって 損失係数を計算すると，流量比や管径比によっては，実 測値とはかなり差を生じることが明らかとなった，そこ で, ここでは, 特に横流入方向の損失係数の実測值をよ り正確に計算できるように $C_{Q}$ の計算式(9)式を新たに作 成した. なお，(2)式と（3）式に関しては，2 方向接合円 形落差マンホールの損失特性に関寸る著者らの研究 ${ }^{7)}$ で 得られた修正式(10)式と（11）式を採用寸る.（9)式の作 成手順は以下の通りである. まず, 図-9 の Type A を除く 主流方向と横流入方向の実測值 $K_{e u}, K_{e l}$ をもとに, (10) 式と（11）式で求めた $K_{o}, C_{D}$ 及び(1) 式から $C_{Q}$ を算出 した. 次に, $C_{Q}$ の值をもとに主流方向と横流入方向のそ れぞれについて最小二乗法による回帰式を求め, $\sin \theta$ を 変数とした一つの式に合成した. なお, モデル式の精度 はF検定によると $5 \%$ の有意性は認められる結果となっ ている.

$$
\begin{gathered}
C_{Q}=(-1.634 \sin \theta+1.252) \\
+(0.816 \sin \theta+0.579) \frac{Q_{l}}{Q_{d}} \\
K_{o}=0.09\left(\frac{b}{D_{d}}\right)(1-\sin \theta)+1.3\left(\frac{b}{D_{d}}\right)^{0.15} \sin \theta \\
C_{D}=\left(\frac{D_{d}}{D_{i}}\right)^{3.2}
\end{gathered}
$$

図-11 と図-12に(1)式と (9)式から(11)式を用いた損失 係数の計算值と実測值との比較を示す. 主流方向に関し て（9)式を用いた場合，(5)式を用いた計算結果とそれほ ど大きな差はないが, 横流入方向に関しては, 流量比が 小さいところで，実測值をほぼ再現できている，現場に 設置されているマンホールに接合する管内径の組み合わ せは非常に多く，全ての組み合わせに対して実験的に検 証することはほとんど不可能であるが，組み合わせの種 類を十分に精査した上で研究を進めれば，より沉用性の 高い計算式を提示できるものと考える. 現在, 図-13に示 すように流入・流出管の段差を考慮した実験を行ってい るところであり，今後管内径の組み合わせを変えた実験 などを行い，(9)式のさらなる検証と段差を考慮した定式 化を行う予定である.

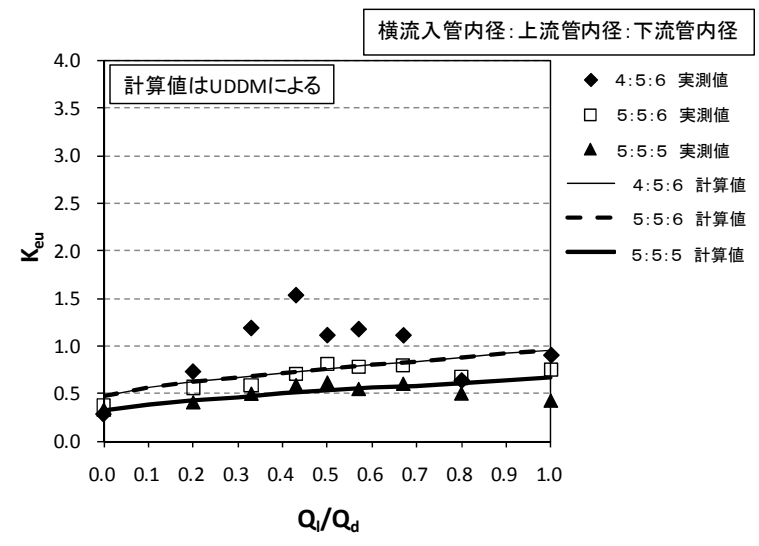

図-9 主流方向の損失係数 $K_{e u}$ と流量比 $Q_{l} / Q_{d}$ との関係

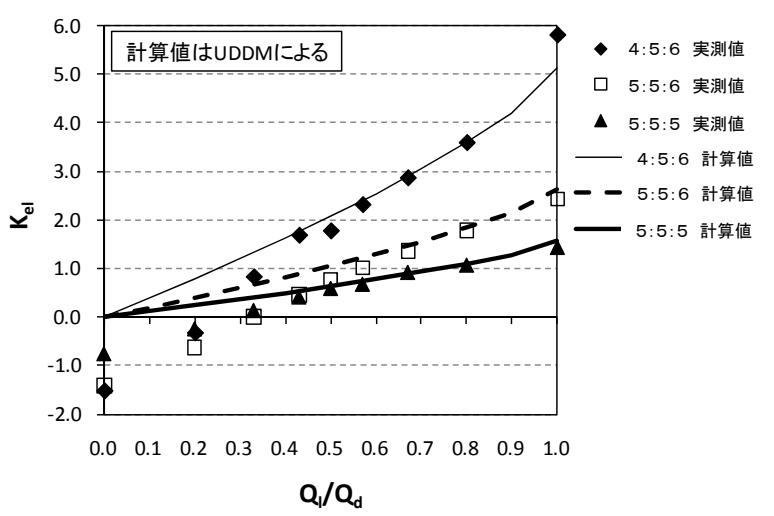

図-10 横流入方向の損失係数 $K_{e l}$ と流量比 $Q_{l} / Q_{d}$ との関係

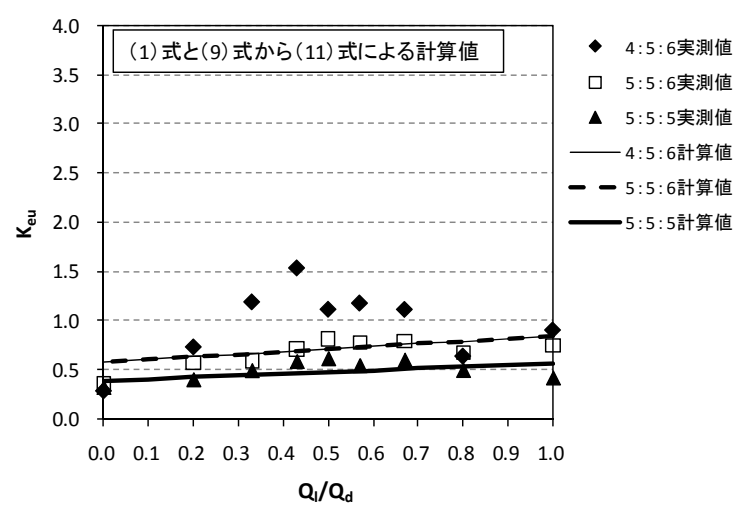

図-11 主流方向の損失係数 $K_{e u}$ と流量比 $Q_{l} / Q_{d}$ との関係 


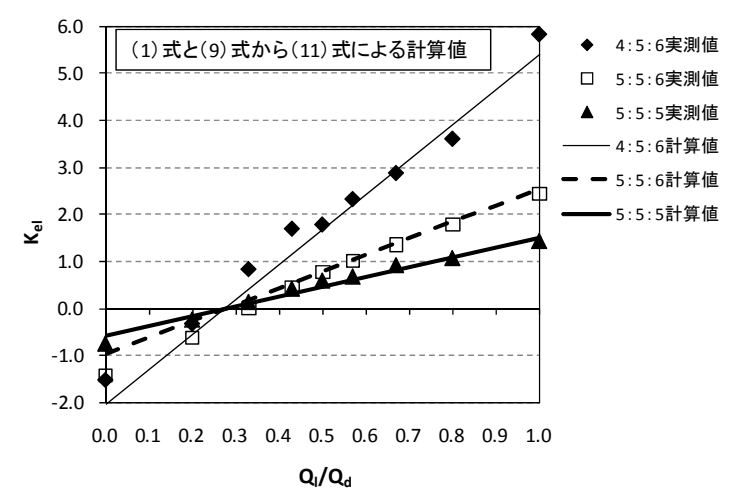

図-12 横流入方向の損失係数 $K_{e l}$ と流量比 $Q_{l} / Q_{d}$ との関係

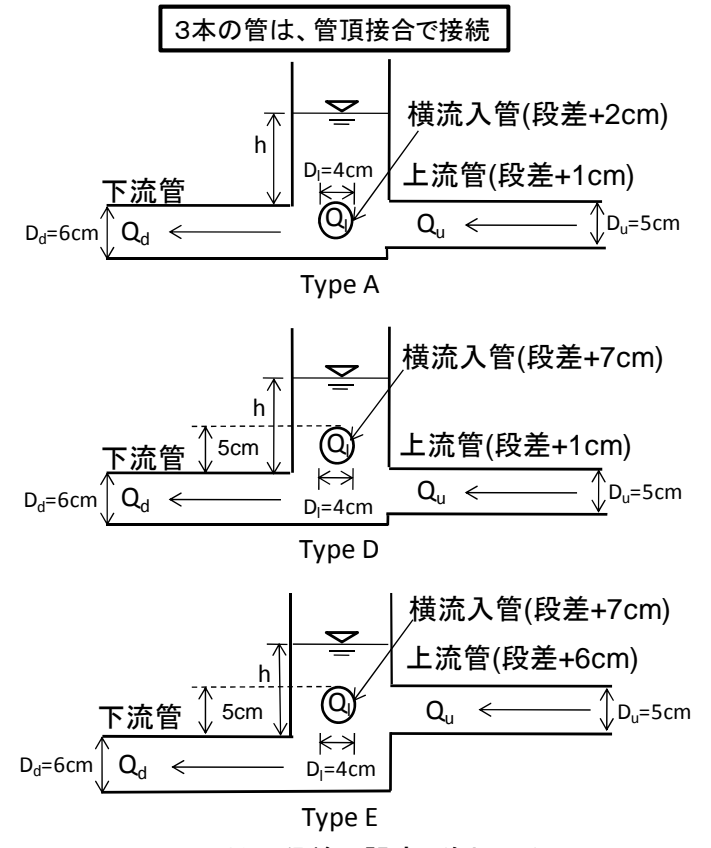

図-13 段差の設定（側面図）

\section{5. 結論}

1) 横流入管の管内径が小さくなると, 主流方向, 横流入 方向，いずれもエネルギー損失係数は大きくなる.

2) 主流方向では，いずれの管径比でも流量比が 0.5 付近 のとき, エネルギー損失係数は最大となる.

3)横流入方向では，いずれの管径比でも横流入管の流量 が増加するにつれて, エネルギ一損失係数も増加する。 この主な理由は，横流入管の流量の増加に伴い，横流 入管からの流入水が直接マンホール側壁、衝突し，速 度水頭の大部分を失うからである。

4) 適用範囲が最も広いと考えられる $\operatorname{UDDM}(2001)^{8}$ に掲 載されている式によりエネルギ一損失係数を求めると, 主流方向では，管内径が全て異径のときに，流量比に よっては，実測值とかなり異なることがわかった。ま た，横流入方向では，流量比が 0 から 0.3 付近で実測 值を再現できないことがわかった。

5) 横流入方向のエネルギー損失係数がより実測值に合う

\section{ように修正式を提示した。}

今後は，本論文とは別に 3 本の管内径が異なる実験を 行い，修正式の妥当性を検証する．さらに，流入・流出 管の段差を考慮した実験を行い，段差をも考慮した式を 考案する。これに関しては，現在実験中であり，より汎 用性の高い計算式を考案する予定である.

\section{参考文献}

1）荒尾慎司, 楠田哲也：2方向接合マンホール部のエネルギー 損失特性-レビューと課題，下水道協会誌，Vol.33，№.396， pp.75-86, 1996.

2) Kusuda, T., Arao, S. and Moriyama, K. : Energy Losses at Junctions and Transient Flow in Sewer Networks, Proc. $6^{\text {th Int. Conf. Urban }}$ Storm Drainage, Vol.1, pp.122-127, 1993.

3) Arao, S. and Kusuda, T. : Energy Losses at Circular Drop Manholes, Proceedings of the 7th ICUSD, Hanover Germany, Vol.1, pp.85-90, 1996.

4) Yen, B. C. : Hydraulics of Sewers, Advances in Hydrosciences, Academic Press, Orland, Florida,Vol.14, pp.1-122, 1986.

5) Larry, W. Mays : STORMWATER COLLECTION SYSTEMS DESIGHN HANDBOOK, McGraw-Hill, pp.6.65-6.84, 2001.

6）荒尾慎司，楠田哲也：3方向接合マンホール部のエネルギー 損失特性-レビューと課題，下水道協会誌，Vol.33，№.397, pp.67-75, 1996.

7）荒尾慎司，楠田哲也 : 管水路流孔における 2 方向接合円形落 差マンホール部の形状損失の定式化，土木学会論文集 G, Vol. 62, No.1, pp.162-170, 2006.

8) Urban Drainage Design Manual, HEC22(http://www.fhwa.dot. gov/ bridge/hec22.pdf), 2001.

9) Sangster, W.M., Wood, H.W., Smerdon, E.T. and Bossy, H.G.: Pressure Changes at Open Junctions in Conduits, Trans.,ASCE,126, pp.364-396, 1961.

10) Marsalek, J. : Head Losses at Selected Sewer Manholes, Special Report 52, American Public Works Association, Chicago, IL, 1985.

11) Lindvall, G. :Head Losses at Surcharged Manholes with a Main Pipe and $90^{\circ}$ Lateral, Proc. $3^{\text {rt }}$ Int. Conf. on Urban Storm Drainage, pp. 137-146, 1984, Chalmers Univ. of Technology, Goetborg, Sweden.

12) 荒尾慎司, 楠田哲也：3方向接合マンホールの損失特性に関 する実験的研究，環境工学研究論文集，Vol.40，pp.421-429, 2003.

13)阿部正毅, 小橋川洋平, 田中敬一：3方向接合円形マンホール の損失特性に関する実験的研究，一下流管径の違いと段差の影 響, 平成 15 年度九州共立大学工学部土木工学科卒業研究概要 集, pp.81-86, 2003.

14）下水道施設計画・設計指針と解説一前編，第 2 章管路施設, 第7節マンホール，日本下水道協会，pp.164-176， 1994. 